\title{
Sleep of Parents Living With a Child Receiving Hospital-Based Home Care: A Phenomenographical Study.
}

Charlotte Angelhoff, Ulla Edéll-Gustfsson and Evalotte Mörelius

Journal Article

\section{Tweet}

N.B.: When citing this work, cite the original article.

Original Publication:

Charlotte Angelhoff, Ulla Edéll-Gustfsson and Evalotte Mörelius, Sleep of Parents Living With a Child Receiving Hospital-Based Home Care: A Phenomenographical Study., Nursing Research, 2015. 64(5), pp.372-380.

http://dx.doi.org/10.1097/NNR.0000000000000108

Copyright: Lippincott, Williams \& Wilkins

http://www.lww.com/

Postprint available at: Linköping University Electronic Press

http://urn.kb.se/resolve?urn=urn:nbn:se:liu:diva-121085

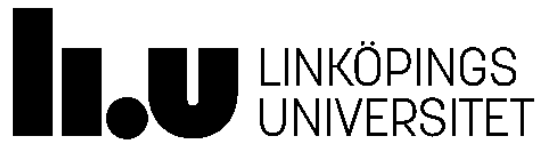


Running head: SLEEP OF PARENTS WITH CHILDREN IN HOME CARE

Sleep of Parents Living with a Child Receiving Hospital-Based Home Care:

A Phenomenographical Study

ACCEPTED: APRIL 30, 2015

Charlotte Angelhoff, RN, MSc

PhD Student

Department of Social and Welfare Studies

Linköping University

Linköping, Sweden

Ulla Edéll-Gustafsson, CCRN, PhD

Professor

Department of Medicine and Health Sciences

Linköping University

Linköping, Sweden

Evalotte Mörelius, RN, MSc, PhD

Associate Professor

Department of Social and Welfare Studies

Linköping University 
Norrköping, Sweden

Author Note

Charlotte Angelhoff, RN, MSc, is PhD student, Department of Social and Welfare Studies, Linköping University, Norrköping, Sweden.

Ulla Edéll-Gustafsson, CCRN, PhD, is Professor, Department of Medicine and Health Sciences, Linköping University, Linköping, Sweden.

Evalotte Mörelius, RN, MSc, PhD, is Associate Professor, Department of Social and Welfare Studies, Linköping University, Norrköping, Sweden.

The authors gratefully acknowledge the participating parents and the pediatric nurse specialists at the Hospital-Based Home Care Services for children involved in this study.

The authors also acknowledge that this study was supported by The Medical Research Council of South East Sweden (FORSS), and the County Council of Östergötland, Sweden. The authors have no conflicts of interest to report.

Corresponding Author: Charlotte Angelhoff, RN, MSc, Department of Social and Welfare Studies, Linköping University, 60174 Norrköping, Sweden. (e-mail: charlotte.angelhoff@liu.se). 


\begin{abstract}
Background: Caring for an ill child at home gives the family the chance to be together in a familiar environment. However, this involves several nocturnal sleep disturbances, such as frequent awakenings and bad sleep quality, which may affect parents' ability to take care of the child and themselves.

Objectives: The aim of this study was to describe parents’ perceptions of circumstances influencing their own sleep when living with a child enrolled in hospital-based home care (HBHC) services.
\end{abstract}

Method: This is a phenomenographical study with an inductive, exploratory design. Fifteen parents (11 mothers and four fathers) with children enrolled in HBHC services were interviewed. Data were analyzed to discover content-related categories describing differences in ways parents experienced sleep when caring for their children receiving HBHC.

Results: Four descriptive categories were detected: sleep influences mood and mood influences sleep; support influences safeness and safeness influences sleep. The child’s needs influence routines and routines influence sleep, and “me time” influences sleep.

Discussion: Sleep does not only affect the parents’ well-being, but also the child's care. Symptoms of stress may limit the parents' capacity to meet the child’s needs. Support, me time, and physical activity were perceived as essential sources for recovery and sleep. It is important for nurses to acknowledge parental sleep in the child's nursing care plan, and help the parents perform self-care to promote sleep and maintain life, health, and well-being. Key Words: children, chronic illness, home care services, parents, qualitative research, sleep 
Sleep of Parents Living with a Child Receiving Hospital-Based Home Care:

A Phenomenographical Study

A child should only be admitted to the hospital if treatment and care cannot be given in the home or in primary care (European Association for Children in Hospital, 2015). Being able to provide care at home makes families' lives more normal, and basic activities, such as sleep, can be easier to manage. Nevertheless, parents have to care for their ill child no matter how tired, stressed, or ill they are themselves (Carter et al., 2012).

Some hospitals offer hospital-based home care (HBHC) services for children, where children with severe illnesses and children in need of frequent medical care can be treated by hospital staff in their homes instead of being hospitalized. Studies have reported that HBHC safely replaces hospital stays for children — at the same cost or less — and that it is greatly preferred by parents (Hansson, Kjærgaard, Schmiegelow, \& Hallström, 2012; Hansson et al., 2013; Tiberg, Carlsson, Carlsson, \& Hallström, 2012). A Cochrane Review stated that parents of children enrolled in HBHC had better coping skills, family functioning, and less anxiety compared to parents with children in traditional care (Parab, Cooper, Woolfenden, \& Piper, 2013). When hospitals do not provide HBHC, parents need to take a greater responsibility of the child's care at home. Parents of children with cancer have reported concern, anxiety, and fear of making mistakes when caring for their child at home between treatment periods (Sari, Yilmaz, Ozsoy, Kantar, \& Çetingul, 2013).

The connection between stress and sleep is well established (Åkerstedt et al., 2012; Morin, Rodrigue, \& Ivers, 2003; Partinen, 1994). Bedtime stress and worries are related to poor sleep (Åkerstedt, Kecklund, \& Axelsson, 2007; Åkerstedt et al., 2012). Sleep is needed for normal 
function and recovery of all body systems (Morin \& Espie, 2004). For recovery, the most important sleep is the deep sleep during the first part of the night. It can be hampered by awakenings during the night, leading to sleepiness and poor recovery (Markov \& Goldman, 2006). Sleep loss is associated with negative parenting behaviors, such as high stress levels, low self-efficacy, and greater irritability in parent-child interactions. It also impacts on parents’ attention, memory, and concentration (Cooklin, Giallo, \& Rose, 2012).

There is an association between children's sleep patterns, parental sleep, and parent daytime functioning (Boergers, Hart, Owens, Streisand, \& Spirito, 2007; Meltzer \& Montgomery-Downs, 2011). If the child has sleep problems or needs attention at night, the time spent awake by parents and disrupted sleep increase significantly (Mörelius \& Hemmingsson, 2014). Sleep loss is a major concern in parents of chronically ill children (Meltzer \& Moore, 2008; Mörelius \& Hemmingsson, 2014; Zupanec, Jones, \& Stremler, 2010). For instance, parents of children with leukemia are affected by changed sleeping habits and disturbed sleep during their children’s cancer treatment (Zupanec et al., 2010). Moreover, poor sleep quality, stress, and depressive symptoms influence quality of life for maternal caregivers of young children with bronchopulmonary dysplasia (Feeley et al., 2014). Constantly dealing with the challenges and struggles of managing a child's needs 24 hours a day is demanding and draining - especially with limited sleep (Koshti-Richman, 2009).

Self-care denotes the activities that are performed by a person to maintain life, health, and well-being. Activities performed on behalf of a socially dependent person with self-care demands, like a parent caring for a child, have been defined as dependent care (Orem, 2001). HBHC decreases anxiety and increases parental satisfaction. On the other hand, sleep disruption and impaired daytime functioning are major concerns for parents performing dependent care for 
their ill children at home. These contradictions are highly interesting to study as they conflict with each other. There is limited research performed on parent's sleep when performing dependent care for their ill child, and not on parents who have a child enrolled in HBHC.

The aim of this study was to describe parents’ perceptions of circumstances influencing their own sleep when living with a child enrolled in HBHC.

\section{Methods}

\section{Design}

This is a phenomenographical study with an inductive, exploratory design.

Phenomenography is the empirical and qualitative study of the different ways people experience phenomena in the world (Marton \& Booth, 1997). In nursing research, phenomenography aims to deal with the differences in how people experience or conceptualize a phenomenon. This is in contrast to phenomenology, where the search for the essences or most invariant meaning of the phenomena is central (Larsson \& Holmström, 2007; Sjöström \& Dahlgren, 2002).

In the present study, a second-order perspective was adopted as the different ways parents perceive circumstances influencing sleep when living with a child enrolled in HBHC were focused upon. The distinction between first- and second-order perspectives deals with the difference between being and considering a statement about the world or a situation. The firstorder perspective refers to statements about the world — the phenomena-and specific situations as experienced by people. The second-order perspective refers to the ways of experiencing the world (the phenomena) and/or the situation in a what and how aspect (Marton \& Booth, 1997). The different ways people experience the phenomena-interpret in terms of distinctly different descriptive categories - which capture the essence of variation in an outcome space. The 
outcome space is the result of a phenomenographic study (Larsson \& Holmström, 2007; Marton \& Booth, 1997).

\section{Setting}

One university hospital and one general hospital in Sweden providing a form of HBHC called "advanced pediatric home care” were included in the study. In advanced pediatric home care, practical support is provided for families with children diagnosed with acute or chronic diseases with complications, children with complications from prematurity, and children in palliative care. This can include children who need intravenous treatments, tube feeding, oxygen treatment, or tracheostomy care. The HBHC team consists of pediatric nurse specialists and pediatricians in collaboration with social workers and physiotherapists. The parents care for their children in their homes. The HBHC team helps the families at home by providing advice and support, performing basic examinations, taking blood samples, educating the families about care and drug administration, and coordinating contacts with pharmacies, physicians, social workers, dieticians, and social services.

HBHC services for children are available during the day, Monday-Friday. Some families have visits every day, others more seldom—depending on the child's illness and need for support. If children need medical care during the night or the weekend, they are admitted to the hospital as there are no HBHC services available at that time.

\section{Data Collection}

The HBHC nurses established contact between the participants and the researchers. Inclusion criteria were Swedish-speaking parents of children enrolled in HBHC. Eighteen parents were asked to participate. Two parents declined, and one parent had a child who had been discharged from HBHC. A total of 11 mothers and four fathers between 27-43 years of age 
were included in the study. To achieve a variation in the perception of the phenomenon, the conditions of the children receiving $\mathrm{HBHC}$ —and the participants' living conditions—-working status, and marital status differed. The sample included parents who had one child, parents with several children (older and younger), and parents who had twins. Seven of the parents slept in the same room as the child enrolled in HBHC. Four parents had a younger child sleeping in their room. One family had night-time nursing assistance provided by the municipality. (Descriptive data of the participants is described in Table 1.) The children were between five months and 12 years old. No child was in palliative care.

The parents were given oral and written information about the study and filled out a consent form before the interview started. In one family, both parents wanted to participate. They were interviewed separately. The interviews were conducted in Swedish. The interview guide comprised a few entry questions, such as, “Tell me, how do you experience your own sleep,” "What influences your sleep,” and "What do you do to prevent sleep?” A subsequent dialogue followed according to the obtained answers (Sjöström \& Dahlgren, 2002). The interviews were conducted during March-October 2011 and April-May 2013, with a median time of 31 minutes.

\section{Ethical Considerations}

The study was approved by the Regional Committee for Medical Research (DNR 2011/1631). The participants were guaranteed confidentiality and were informed that they could withdraw from the study at any time-without explanation or consequences to their children's future care. One of the researchers worked as a pediatric nurse at one of the hospitals, so there was a chance that she might meet the participating parents in other situations. The research group discussed the ethical and moral aspects of this carefully, and the parents were informed about the situation when they were first contacted. No parent objected to participation because of this 
possibility. The interviews were coded, and the code list and transcripts were kept in separate, secure locations.

\section{Data Analysis}

Data were analyzed in seven steps according to Sjöström and Dahlgren (2002). The interviews were transcribed verbatim and read several times for familiarization of data. A compilation was made of every participant's most significant answers regarding the phenomenon. The third step was condensation to find the essence of longer answers and conversations. These three steps of familiarization with the material were given a lot of time and were continuously discussed in the research group. The fourth step was a preliminary grouping of similar individual responses into subcategories. The subcategories were compared to distinguish categories and find variations and similarities. The grouping and comparison steps were repeated several times during the analysis to find descriptive and distinct categories. The descriptive categories were named to emphasize their essence, and a contrastive comparison was made of the descriptive categories, with a description of every category's unique character and their connection (Sjöström \& Dahlgren, 2002). The descriptive categories constituted the outcome space (Larsson \& Holmström, 2007; Marton \& Booth, 1997). The categories were named in English during the analysis. The quotations were translated by a native Englishspeaking, professional translator before submission. The original quotations in Swedish are shown alongside the English translation (see Supplemental Digital Content).

\section{Credibility}

In phenomenographical studies, credibility is based on a precise description of each part of the research process, the perspective applied to the phenomenon, and a careful description of the analyses and conclusions that make it possible to replicate the study. The findings of the 
descriptive categories do not have to be replicable. However, they need to reach a high level of intersubjective agreement if they are to be used by other researchers. The relationship between the empirical data and the descriptive categories is at the core of credibility (Sjöström \& Dahlgren, 2002). The research group continuously discussed the analysis process to find descriptive categories that were trustworthy and close to the collected data, as interpretation is not desirable. Quotations from the interviews are used to support the relevance of the descriptive categories (Sjöström \& Dahlgren, 2002).

\section{Findings}

The outcome space consists of four categories describing parents' perceptions of circumstances influencing their own sleep when living with a child enrolled in HBHC: sleep influences mood, and mood influences sleep; support influences safeness and safeness influences sleep; the child's needs influence routines and routines influence sleep; and me time influences sleep.

\section{Sleep Influences Mood and Mood Influences Sleep}

In this descriptive category, the parents described how mood and sleep influenced each other. Concern and anxiety about the child's health, uncertainty about the future, and worries about work and the financial situation influenced parents’ sleep negatively. Most had constant difficulties falling asleep, and troubling thoughts kept them awake at night.

Most of the time, I find it really hard ... Since I rarely get a proper sleep, it feels like it's better to stay awake; as I don't know what will happen during the night . . I I don't long to go to bed, even if I'm really tired (P8).

However, some parents did not experience any sleep disturbances at all, unless the child was in a worse condition than usual, or if something worrying had happened during the day. 
I think it's nice to go to bed ... I don't feel anxious about going to sleep; I don't have any problems sleeping (P11).

Some parents woke up several times after falling asleep due to worries or troubling thoughts. They could wake up and check on their child — even if the child was sleeping-just to be sure that everything was fine. They did not want to fall into a deep sleep as they were afraid they would not wake up if the child needed their attention.

Parents perceived that sleep loss led to forgetfulness, tiredness, impatience with the family and partner, and depressive moods. They had a constant bad conscience about not doing enough for their sick child, and for making the other family members step aside as the sick child demanded all their attention. They had no energy to get things done and felt sad about their own negative behavior.

My brain goes a bit muddled ... I don't think I have dementia, I don't think so, but . . . well, I can't think of words ... forget, can't remember names and things like that ... typical signs of sleep loss, I guess ... (P9).

I feel tired, not rested, and I don't feel like spending time with the children . . . I just want to go, but they follow me around ... it's different when I feel alert, then I can play with them all the time ... I feel inadequate (P15).

One parent had started to drink alcohol almost every evening, which affected his mood negatively. He expressed that he had a guilty conscience about his habit, but perceived that alcohol helped him relax and fall asleep, even though the sleep was disrupted by several awakenings.

\section{Support Influences Safeness and Safeness Influences Sleep}


In this descriptive category, the parents described how they needed to feel safe to go to sleep and how this was influenced by practical and emotional support. Safeness was a prerequisite for sleep and relaxation. Feeling safe and secure, and having the ability to let go of the need for control was perceived as important for sleep duration and sleep quality. All parents were satisfied with being in a familiar environment at home with their child.

When I feel safe ... when everybody is happy and there with me, and I feel safe. Then, I can fall asleep, that's when I get the best sleep (P4).

The parents appreciated being able to manage their own time instead of being in the hospital where they had to follow policies and rules.

Practical and emotional support from a partner was perceived to be of utmost importance. Shared responsibility for the child's care and everyday household tasks — and having someone to talk to during difficult times_-improved feelings of safeness and influenced sleep positively. To optimize the chance of getting some sleep, some parents shared the responsibility of their child's night-time needs by making a schedule. They took the night watch every other night so that the other parent could have a full night's sleep, or split the night in two parts and took responsibility for the child's needs for half a night each. When the parents felt secure and could rely on their partner, they perceived that their sleep was deeper and uninterrupted.

I sleep like a log the nights when he takes charge of everything. I just let go of everything, I suppose, and I guess I let go of all responsibilities too. And trust the other person (P2). However, some parents mentioned that it was hard to let go of control and relax, even if their partner took full responsibility for the child's needs. This influenced their sleep negatively as they woke up frequently, even though their partner was there. The parent living without a partner lacked this support. She had to take full responsibility herself, which was tough and draining. She could never relax, which influenced sleep negatively. 
Practical and social support from friends and relatives helped the parents to adapt to daily life. However, some parents perceived that the child's grandparents were afraid of doing something wrong, which could be harmful, if they took care of the child on their own. Other parents perceived that the grandparents were not interested in their adult children’s family situation. Some parents perceived feelings of isolation, loneliness, and sadness, which influenced their sleep negatively.

Practical support from the healthcare system, organizations, and authorities gave rise to feelings of safeness. All parents expressed satisfaction with having the option to contact the HBHC nurses. This was a way to quickly reach the healthcare services when they needed advice, prescriptions, or practical support. The possibility to have a nurse coming to their homes was much appreciated-especially among those who did not live near the hospitals in the cities. Some parents found support in encouraging organizations specialized in their child's diagnosis. It was perceived as valuable to meet and talk to other parents in the same situation.

Three of the families were offered night-time assistance; one family accepted. The parents who declined night-time assistance perceived that having a private life was more important, and they were afraid of losing their privacy if someone else was in their house at night, interrupting and disturbing their family life.

Several other aspects are affected; even if sleep is improved, what kind of private life will we have? How will we be able to sit and watch a movie if someone else is sitting there? (P8).

The parent who accepted night-time assistance felt uncomfortable and expressed that he felt that he could not walk around as he wanted in the house, in case the assistant should come down the stairs. He found it difficult to relax and go to sleep with someone constantly present.

\section{The Child's Needs Influence Routines and Routines Influence Sleep}


In this descriptive category, the parents described how they changed their routines and behavior to the child's needs in order to improve sleep. All the parents expressed that they put their child and the child's needs first. They perceived that their thoughts and actions were based on the child's needs, and they had high demands on themselves. The parents changed their routines and behavior to live normally, despite the problems their child's illness could cause. They perceived high demands from the society, their families, and from themselves. Changed routines and increased responsibility made them feel stressed. Not only should they be parents, but they should also care for their child with special needs 24 hours a day. One parent expressed that she had learned how to care for her child's special needs and that she felt as if she was a nurse.

Routines facilitated the child's physical, emotional, and health-related needs during the day. The routines included ordinary daily doings, but could also include preparation and administration of medication and special food, training schedules, habilitation, and meetings with healthcare staff. The parents planned their time according to the child's needs. Thus, a meeting at an unsuitable time could have major consequences if the child needed medication, food, or a nap at that time. Some parents also tried to adjust their own needs to the child's routines. While the child was sleeping, they could take a nap, go for a walk, or manage as much as possible of everyday household tasks. One parent had no experience of changing her routines or behavior. On the other hand, her child was older than the others, and had had very few recent healthrelated problems.

I have to adjust to her needs; that's the important thing. She has to have what she needs (P6).

The parents planned and prepared their activities in the evening to optimize time for sleep. Some parents had changed their bedtime routines and went to bed earlier to optimize their 
sleeping time. They had learned the child's sleep pattern and tried to adjust their own sleep time to that. This was a major adjustment for most of the parents, as they were used to staying up later. Some parents expressed that they felt guilty toward their partner if they did not go to bed at the same time.

Now I know that he wakes up between half past six and half past seven, so I've adjusted my own sleep routines ... I can't stay up to midnight, I have to, well prioritize, and go to bed earlier... (P2).

Nighttime awakenings were connected to the child's needs. The child crying, and a continuum of tube feeding, medical treatments, e.g., inhalations, and/or breathing support, such as bilevel positive airway pressure (BiPAP), drained the parents’ energy.

You need to get up and make the food and turn on the machine, and then it beeps when it's ready, and then that wakes you up and you have to remove the tube and clean it at night ... It's a lot (P9).

Sometimes, the parents found it difficult to go back to sleep and eventually gave up. One parent mentioned that he had just a few hours of sleep before he woke up again and started to work as he could not go back to sleep. However, some parents did not perceive any problems at all going back to sleep.

\section{“Me Time” Influences Sleep}

In this descriptive category the parents described how me time and physical activity influenced their sleep. The parents perceived that time for themselves, expressed as "me time,” could improve sleep. Time for hobbies, meeting with friends, physical activity, work, and relaxation were perceived as valuable time for recovery and improved sleep. Me time depended on support from partners, friends, and relatives. The parents also needed to feel safe enough to give up control and leave the child with someone else. 
So far, we've not had that many babysitters, but we've talked about how nice it would be to be alone without the children sometimes. I think that would make us sleep well (P13).

However, me time was not prioritized by the parents. Some parents expressed that they felt like bad parents if they took time just for themselves. They felt guilty if they had me time instead of being with their children or partner, even though they wanted and needed time alone to manage daily life and improve sleep.

I've put myself last on the list of priorities. The children come first, then my husband, and then maybe I can get to do something ... if I can give up control and feel that it's OK for me to take up some space... (P8).

The parents who had the opportunity to take me time perceived that they could recover, and that this influenced their well-being and sleep in a positive way. Me time was facilitated in families where a parent could be relieved by their partner, or where the children were old enough to manage on their own for a while. Watching TV or using the computer could be enough for some of the parents, whereas others wanted to do some physical activity or socialize with friends. Going to work was mentioned as one option for me time, and the parents who were on parental benefit or on temporary parental benefit to care for their child longed to go back to work and meet colleagues. One parent expressed that she longed for silence.

I take me time in the evenings-when the others are asleep. That's when I take time to myself. I mainly watch a movie, or sit in front of the computer playing a game, spend time on my own ... I can shut out everything else and just focus on that for a while instead. That's nice (P4). I never feel relaxed, I never do . . I I keep thinking about things. That's why I always have music on, because then I can't hear my own thoughts, and I can focus on the music instead. I suppose that's one way to relax... (P3). 
Physical activity was perceived as another important source for well-being and sleep. It could consist of a walk outdoors, an hour at the gym, or playing different kind of sports. Parents with small children enjoyed taking a walk with the baby carriage, and those who had a dog were thankful that they were "forced" to go out every day. The parents who used to exercise regularly could feel frustrated if they missed a workout and found it harder to fall asleep at the end of those days.

When I'm outside I can clear my head in a different way, and I think about the things that I would perhaps think about at night otherwise. The times I'm outside, I feel like 'God, this is good.' And then I can fend off those thoughts later (P12).

It was considered important to have an adult life. The parents perceived that they had fallen into roles as mothers/fathers, nurses, physiotherapists, and housekeepers. They expressed a need for "adult time" with their partner, when they could discuss, reflect, comfort, and take care of each other. They missed time to go away and do things together. This could entail anything from going to the supermarket together to having private time just to themselves.

Then we got away, and that was awesome. It was like two-three hours to ourselves. That was cool; it was like the first time, so that was good ... (P13).

\section{Discussion}

It is important that nurses understand the energy-draining effects of dependent care in the home and the stress that is associated with it (Orem, 2001). The findings of our study identify parents' perceptions of circumstances influencing their own sleep when living with a child enrolled in HBHC. Those who were in a good mood and felt safe found it easier to sleep without any disruptions. Troubling thoughts, bedtime worries, anxiety, and stress affected the parents' sleep negatively. This is supported by findings in earlier studies (Édell-Gustafsson, Angelhoff, Johnsson, Karlsson, \& Mörelius, 2015; Klassen et al., 2012). Forgetfulness, tiredness, impatience 
with the family and partner, and depressive mood resulting from poor sleep can be indicators of cognitive and emotional stress symptoms; symptoms that may limit the parents' capacity to meet the child and family's needs and demands. This affects not only a range of adverse child outcomes, but also compromises confidence, competence, and self-esteem (Cooklin et al., 2012).

Safeness was a prerequisite for sleep and relaxation. The possibility to have the child treated in their own home, supported by the HBHC team, was highly valued by the parents. Parents in neonatal hospital care have described that taking care of themselves and their infant in a private room improved sleep and decreased stress (Édell-Gustafsson et al., 2015). However, the HBHC nurse must be sensitive to each family’s need for integrity when entering their home, as privacy and integrity were important aspects for all the families.

Shared responsibility and practical and social support from others helped the parents to handle the struggles of daily life, but were not enough to facilitate sleep. The "demand-controlsupport” model (Karasek \& Theorell, 1990) describes how the combination of perceived demands and perceived control affects work-related stress. The parents in our study performed dependent care for their ill children—which is comparable to work (Orem, 2001). High demands in combination with low perceived control create stress responses that may lead to psychological or physical health problems, such as sleep disruption. On the other hand, social contacts affect basic psychological processes that are important for maintaining long-term health and obtaining new knowledge (Karasek \& Theorell, 1990). Further, a strong social network plays an important role in maintaining parents’ social health (Klassen et al., 2012).

Some parents wished for more practical support from relatives and friends in order to relieve them in their daily lives and facilitate sleep. This is in contrast with findings by Sari et al. (2013), where parents received all types of support from their families and surroundings. This is 
considered to be the result of the Turkish family structure where family members are close to each other. In Sweden, the family structure is different; families mostly live by themselves and grandparents sometimes live far away. However, Swedish grandparents of premature infants have described that they want to be engaged, involved, strong, and supportive for the parents, but do not know what is expected of them (Frisman, Eriksson, Pernehed, \& Mörelius, 2012).

The parents' lives revolved around their child’s needs and schedule. They adjusted their routines and behavior to manage daily life, and tried to find gaps for some time to themselves, expressed as me time. Me time has been described as a coping strategy in mothers of children with autism spectrum disorders (Kuhaneck, Burroughs, Wright, Lemanczyk, \& Darragh, 2010).

The parents in our study perceived that me time was important for psychological wellbeing, but depended on relief from caring. Similar findings were found in a study of U.S. caregivers, which also describes how parents traded sleep for me time (Larson \& Miller-Bishoff, 2014). The parents in our study found it easier to relax in the evening if they had me time. On the other hand, they found it hard to prioritize time for themselves as they felt that their child and family needed them.

Physical activity was mentioned as another important source for sleep and recovery. Stress may decrease the efforts to be physically active (Stults-Kolehmainen \& Sinha, 2014). Single parents of children with cancer have reported that they stay indoors for long periods of time, without being able to be active (Klassen et al., 2012). However, mothers of children with disabilities have reported fewer sleep disruptions when participating in health-promoting activities (Bourke-Taylor, Pallant, Law, \& Howie, 2013).

To our knowledge, this is the first study focusing on parental sleep while living with a child enrolled in HBHC. The study included participants from two different hospitals receiving 
the same kind of HBHC. Hospitals might provide HBHC differently. A strength with the present study is that the sample includes both mothers and fathers of children of different ages—with different diagnoses and severity of illness_-in order to capture a variety of perceptions of the phenomenon. One limit for interpreting the results could be that we did not ask for socioeconomic status. However, we found variations in marital status, working status, and living conditions (Table 1).

In Sweden there are generous terms for parental benefit and temporary parental benefit with economic compensation from the state, which might have implications for the interpretations of the findings. The system allows parents to stay at home with their child, 0-8 years old, for 480 days in total. Out of these 480 days, at least 60 must be taken by the father, to improve gender equality. If the child, 0-12 years old, becomes ill, the parents are allowed to take temporary parental benefit to stay at home from work and care for the child (Ministry of Health and Social Affairs, 2014).

\section{Implications for Clinical Practice}

Nursing interventions are needed to promote sleep and maintain life, health and well-being in parents with children enrolled in HBHC. Even though HBHC nurses do not have direct responsibility for the care of the parent, parents should be included in the nursing care plan as the child's care is affected by the parents' well-being.

Nursing includes physical and emotional help, and securing help from others (Orem, 2001). The HBHC nurse should encourage parents be more physically active and to take me time, as it is an essential self-care prerequisite to balance activity and rest (Orem, 2001). Families could also benefit from HBHC nurses encouraging them to communicate with their relatives and friends about their expectations and the practical and emotional support they need to handle the 
daily life situation and decrease feelings of stress. By receiving physical and emotional support, parents can be helped to initiate or endure a task, think about the situation, or make decisions (Orem, 2001). These decisions could be of great importance to the child's care and future.

\section{Implications for Future Research}

More studies focusing on parental sleep, stress, and health while living with an ill child are needed. The findings in our study are valuable when planning an intervention study aimed to improve sleep in parents of children in HBHC. We suggest that future studies include more fathers and single parents to gain an even more comprehensive view of the studied phenomenon.

\section{Conclusion}

It is important to identify perceptions of sleep in parents with the demanding function of providing dependent care for their ill child. Cognitive and emotional symptoms of stress related to poor sleep do not only affect the parents’ well-being, but also the child’s care. More studies focusing on parental sleep, stress, and health while living with an ill child are needed to gain a deeper understanding and a holistic perspective of the phenomenon. 


\section{References}

Åkerstedt, T., Kecklund, G., \& Axelsson, J. (2007). Impaired sleep after bedtime stress and worries. Biological Psychology, 76, 170-173. doi:10.1016/j.biopsycho.2007.07.010

Åkerstedt, T., Orsini, N., Petersen, H., Axelsson, J., Lekander, M., \& Kecklund, G. (2012). Predicting sleep quality from stress and prior sleep-A study of day-to-day covariation across six weeks. Sleep Medicine, 13, 674-679. doi:10.1016/j.sleep.2011.12.013

Boergers, J., Hart, C., Owens, J. A., Streisand, R., \& Spirito, A. (2007). Child sleep disorders: Associations with parental sleep duration and daytime sleepiness. Journal of Family Psychology, 21, 88-94. doi:10.1037/0893-3200.21.1.88

Bourke-Taylor, H., Pallant, J. F., Law, M., \& Howie, L. (2013). Relationships between sleep disruptions, health and care responsibilities among mothers of school-aged children with disabilities. Journal of Paediatrics and Child Health, 49, 775-782. doi:10.1111/jpc.12254

Carter, B., Coad, J., Bray, L., Goodenough, T., Moore, A., Anderson, C., . . W Widdas, D. (2012). Home-based care for special healthcare needs: Community children's nursing services. Nursing Research, 61, 260-268. doi:10.1097/NNR.0b013e31825b6848

Cooklin, A. R., Giallo, R., \& Rose, N. (2012). Parental fatigue and parenting practices during early childhood: An Australian community survey. Child: Care, Health and Development, 38, 654-664. doi:10.1111/j.1365-2214.2011.01333.x

Édell-Gustafsson, U., Angelhoff, C., Johnsson, E., Karlsson, J., \& Mörelius, E. (2015). Hindering and buffering factors for parental sleep in neonatal care. A phenomenographic study. Journal of Clinical Nursing, 24, 717-727. doi:10.1111/jocn.12654

European Association for Children in Hospital. (2015). The 10 articles of the EACH charter. Retrieved from http://www.each-for-sick-children.org/each-charter.html 
Feeley, C. A., Turner-Henson, A., Christian, B. J., Avis, K. T., Heaton, K., Lozano, D., \& Su, X. (2014). Sleep quality, stress, caregiver burden, and quality of life in maternal caregivers of young children with bronchopulmonary dysplasia. Journal of Pediatric Nursing, 29, 29-38. doi:10.1016/j.pedn.2013.08.001

Frisman, G. H., Eriksson, C., Pernehed, S., \& Mörelius, E. (2012). The experience of becoming a grandmother to a premature infant—A balancing act, influenced by ambivalent feelings. Journal of Clinical Nursing, 21, 3297-3305. doi:10.1111/j.1365-2702.2012.04204.x

Hansson, H., Kjærgaard, H., Johansen, C., Hallström, I., Christensen, J., Madsen, M., \& Schmiegelow, K. (2013). Hospital-based home care for children with cancer: Feasibility and psychosocial impact on children and their families. Pediatric Blood \& Cancer, 60, 865-872. doi:10.1002/pbc.24474

Hansson, H., Kjærgaard, H., Schmiegelow, K., \& Hallström, I. (2012). Hospital-based home care for children with cancer: A qualitative exploration of family members’ experiences in Denmark. European Journal of Cancer Care, 21, 59-66. doi:10.1111/j.13652354.2011.01280.x

Karasek, R. \& Theorell, T. (1990). Healthy work, stress, productivity, and the reconstruction of working life. New York; Basic Books.

Klassen, A. F., Gulati, S., Granek, L., Rosenberg-Yunger, Z. R. S., Watt, L., Sung, L., ... Shaw, N. T. (2012). Understanding the health impact of caregiving: A qualitative study of immigrant parents and single parents of children with cancer. Quality of Life Research, 21, 1595-1605. doi:10.1007/s11136-011-0072-8

Koshti-Richman, A. (2009). Caring for a disabled child at home: Parents’ views. Paediatric Nursing, 21, 19-21. 
Kuhaneck, H. M., Burroughs, T., Wright, J., Lemanczyk, T., \& Darragh, A. R. (2010). A qualitative study of coping in mothers of children with an autism spectrum disorder. Physical \& Occupational Therapy in Pediatrics, 30, 340-350. doi:10.3109/01942638.2010.481662

Larson, E., \& Miller-Bishoff, T. (2014). Family routines within the ecological niche: An analysis of the psychological well-being of U.S. caregivers of children with disabilities. Frontiers in Psychology, 5, 495. doi:10.3389/fpsyg.2014.00495

Larsson, J., \& Holmström, I. (2007). Phenomenographic or phenomenological analysis: Does it matter? Examples from a study on anaesthesiologists’ work. International Journal of Qualitative Studies on Health and Well-Being, 2, 55-64. doi:10.1080/17482620601068105

Markov, D., \& Goldman, M. (2006). Normal sleep and circadian rhythms: Neurobiologic mechanisms underlying sleep and wakefulness. Psychiatric Clinics of North America, 29, 841-53. doi:10.1016/j.psc.2006.09.008

Marton, F., \& Booth, S. (1997). Learning and awareness. Mahwah, NJ: Erlbaum.

Meltzer, L. J., \& Montgomery-Downs, H. E. (2011). Sleep in the family. Pediatric Clinics of North America, 58, 765-774. doi:10.1016/j.pcl.2011.03.010

Meltzer, L. J., \& Moore, M. (2008). Sleep disruptions in parents of children and adolescents with chronic illnesses: Prevalence, causes, and consequences. Journal of Pediatric Psychology, 33, 279-291. doi:10.1093/jpepsy/jsm118

Ministry of Health and Social Affairs. (2014). Parental insurance and allowances to parents in Sweden. Retrieved from http://www.government.se/sb/d/15473/a/183497 
Mörelius, E., \& Hemmingsson, H. (2014). Parents of children with physical disabilitiesPerceived health in parents related to the child's sleep problems and need for attention at night. Child: Care, Health and Development, 40, 412-418. doi:10.1111/cch.12079

Morin, C. M., \& Espie, C. A. (2004). Insomnia: A clinical guide to assessment and treatment. New York, NY: Springer Science.

Morin, C. M., Rodrigue, S., \& Ivers, H. (2003). Role of stress, arousal, and coping skills in primary insomnia. Psychosomatic Medicine, 65, 259-267.

Orem, D. E. (2001). Nursing concepts of practice (6th ed.). St. Louis, MO: Mosby.

Parab, C. S., Cooper, C., Woolfenden, S., \& Piper, S. M. (2013). Specialist home-based nursing services for children with acute and chronic illnesses. Cochrane Library. doi:10.1002/14651858.CD004383.pub3

Partinen, M. (1994). Sleep disorders and stress. Journal of Psychosomatic Research, 38, 89-91. doi:10.1016/0022-3999(94)90139-2

Sari, H. Y., Yilmaz, M., Ozsoy, S., Kantar, M., \& Çetingul, N. (2013). Experiences of parents with the physical care needs at home of children with cancer: A qualitative study. Cancer Nursing, 36, 385-393. doi:10.1097/NCC.0b013e3182a0e221

Sjöström, B., \& Dahlgren, L. O. (2002). Applying phenomenography in nursing research. Journal of Advanced Nursing, 40, 339-345. doi:10.1046/j.1365-2648.2002.02375.x

Stults-Kolehmainen, M. A., \& Sinha, R. (2014). The effects of stress on physical activity and exercise. Sports Medicine, 44, 81-121. doi:10.1007/s40279-013-0090-5

Tiberg, I., Carlsson, K. S., Carlsson, A., \& Hallström, I. (2012). Metabolic control, healthcare satisfaction and costs 1 month after diagnosis of type 1 diabetes: A randomised controlled 
trial of hospital-based care vs. hospital-based home care. Pediatric Diabetes, 13, 625631. doi:10.1111/j.1399-5448.2012.00879.x

Zupanec, S., Jones, H., \& Stremler, R. (2010). Sleep habits and fatigue of children receiving maintenance chemotherapy for ALL and their parents. Journal of Pediatric Oncology Nursing: Official Journal of the Association of Pediatric Oncology Nursing, 27, 217-228. doi:10.1177/1043454209358890 
TABLE 1. Parent Characteristics

\begin{tabular}{|c|c|c|c|c|}
\hline \multirow[b]{2}{*}{ Characteristic } & \multicolumn{2}{|c|}{$\begin{array}{l}\text { Mothers } \\
(N=11)\end{array}$} & \multicolumn{2}{|c|}{$\begin{array}{l}\text { Fathers } \\
(N=4)\end{array}$} \\
\hline & $n$ & $(\%)$ & $n$ & $(\%)$ \\
\hline \multicolumn{5}{|l|}{ Marital status } \\
\hline Married & 4 & $(36.4)$ & 3 & $(75.0)$ \\
\hline Cohabiting & 6 & $(54.6)$ & 1 & $(25.0)$ \\
\hline Single & 1 & $(9.1)$ & 0 & $(0.0)$ \\
\hline \multicolumn{5}{|l|}{ Working status } \\
\hline Working & 2 & $(18.2)$ & 2 & $(50.0)$ \\
\hline Parental benefit & $6^{a}$ & $(54.6)$ & 1 & (25.0) \\
\hline Temporary parental benefit & 1 & $(9.1)$ & 1 & $(25.0)$ \\
\hline Unemployed & 2 & $(18.2)$ & 0 & $(0.0)$ \\
\hline \multicolumn{5}{|l|}{ Living conditions } \\
\hline Apartment & 3 & $(27.3)$ & 1 & $(25.0)$ \\
\hline Terraced house & 3 & $(27.3)$ & 0 & $(0.0)$ \\
\hline Detached house & 5 & $(45.5)$ & 3 & (75.0) \\
\hline \multicolumn{5}{|l|}{ Children in household } \\
\hline One & 4 & $(36.4)$ & 1 & $(25.0)$ \\
\hline Two & 4 & $(36.4)$ & 1 & $(25.0)$ \\
\hline Three & 2 & $(18.2)$ & $1^{\mathrm{c}}$ & $(25.0)$ \\
\hline Four & 1 & $(9.1)$ & 1 & $(25.0)$ \\
\hline Parents with twins & 0 & $(0.0)$ & 2 & $(50.0)$ \\
\hline \multicolumn{5}{|l|}{ Parent sleeping arrangement } \\
\hline Index child ${ }^{d}$ sleeps in parent room & 5 & $(45.5)$ & 2 & $(50.0)$ \\
\hline Younger child sleeps in parent room & 3 & $(27.3)$ & 1 & $(25.0)$ \\
\hline Parents with nighttime nursing assistance & 0 & $(0.0)$ & 1 & $(25.0)$ \\
\hline \multicolumn{5}{|l|}{ Child health conditions $^{d}$} \\
\hline Endocrine system disease & 2 & $(18.2)$ & 0 & $(0.0)$ \\
\hline Congenital heart defect & 1 & $(9.1)$ & 0 & $(0.0)$ \\
\hline Cystic fibrosis & 2 & $(18.2)$ & 1 & $(25.0)$ \\
\hline Esophageal atresia & 1 & $(9.1)$ & 0 & $(0.0)$ \\
\hline Spinal muscular atrophy & 1 & (9.1) & 0 & $(0.0)$ \\
\hline Chromosome aberrations & 1 & (9.1) & 0 & $(0.0)$ \\
\hline Biliary tract atresia & 1 & (9.1) & 0 & $(0.0)$ \\
\hline Gastroschisis & 0 & $(0.0)$ & 1 & $(25.0)$ \\
\hline Prematurely-born with complications & 2 & $(18.2)$ & 2 & $(50.0)$ \\
\hline
\end{tabular}

Note. ${ }^{\mathrm{a} T w o}$ mothers were on parental benefit with younger siblings. ${ }^{b}$ Less than 18 years of age. ${ }^{\mathrm{c} O n e}$ father had three children living at home all the time, and four children who lived with the family every other weekend.

${ }^{\mathrm{d} C h i l d ~ e n r o l l e d ~ i n ~ h o s p i t a l-b a s e d ~ h o m e ~ c a r e ~ s e r v i c e s . ~}$ 


\section{Supplemental Digital Content}

\section{Quotations in original language (Swedish) and after translation to English}

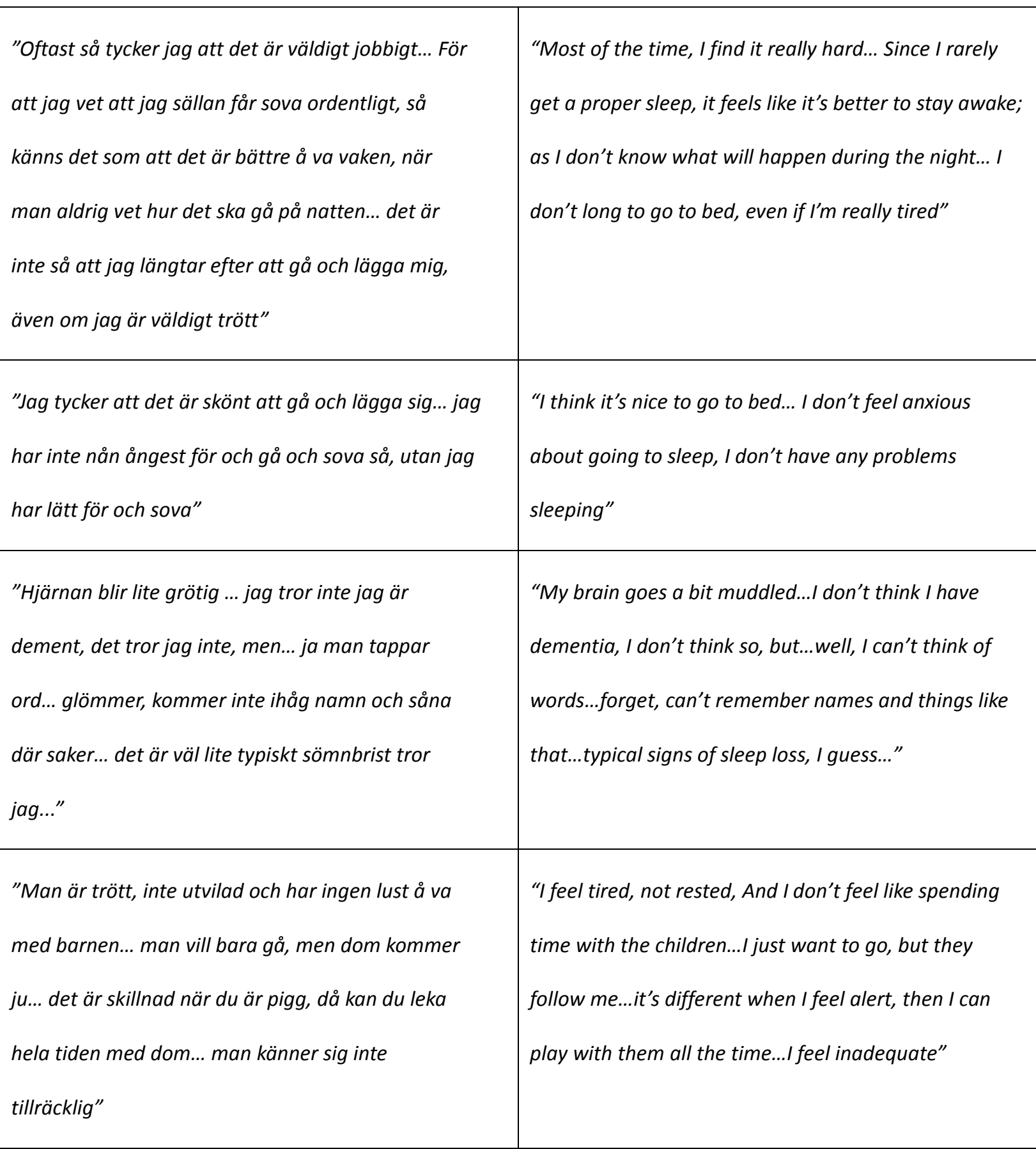


"När jag känner mig trygg... när alla är glada och går runt omkring mig och jag känner mig trygg. Då somnar jag, då sover jag bäst"

"Dom nätterna när han liksom tar allt då sover jag stenhårt, för då släpper man väl allt och blir väl att man släpper allt ansvar också. Litar på den andre"

"Då är det ju så mycket annat som påverkas, även om sömnen blir bättre så känns det som att ja vad har vi för privatliv då? Hur ska vi kunna sitta och kolla på film om det är nån annan som sitter där?”

"Det är ju det att man måste ju rätta sig efter hennes behov, det är ju det viktiga, hon måste få sitt som hon ska ha"

"Nu vet jag att han vaknar liksom mellan halvsju och halvåtta, då får man ju faktiskt också lägga om sin egen sömn... då kan man inte gå uppe till tolv utan då får man, ja prioritera å gå och lägga sig lite tidigare också..."

"... man ska upp och göra mat och liksom sätta igång maskinen och så piper den när det är klart och då vaknar man av den och då ska man ta bort slangen
"When I feel safe... when everybody is happy and there with me, and I feel safe. Then, I can fall asleep, that's when I get the best sleep"

"I sleep like a log the nights when he takes charge of everything. I just let go of everything, I suppose, and I guess I let go of all responsibilities too. And trust the other person"

"Several other aspects are affected; even if sleep is improved, what kind of private life will we have? How will we be able to sit and watch a movie if someone else is sitting there?"

"I have to adjust to her needs, that's the important thing. She has to have what she needs"

"Now I know that he wakes up between half past six and half past seven, so I've adjusted my own sleep routines...I can't stay up to midnight, I have to, well prioritize, and go to bed earlier..."

"You need to get up and make the food and turn on the machine, and then it beeps when it's ready, and then that wakes you up and you have to remove the tube and clean it at night...It's a lot" 


\begin{tabular}{|c|c|}
\hline $\begin{array}{l}\text { och sen ska man ju rengöra den på natten... Så det är } \\
\text { mycket." }\end{array}$ & \\
\hline "Än så länge har vi ju inte haft så mycket barnvakter & "So far, we've not had that many babysitters, but \\
\hline sådär men, men det har vi sagt det skulle va väldigt & we've talked about how nice it would be to be alone \\
\hline skönt och nån gång liksom, ha barnfritt liksom så. Då & without the children sometimes. I think that would \\
\hline tror jag vi skulle sova bra." & make us sleep well" \\
\hline "Jag har placerat mig själv på sista plats när det gäller & "I've put myself last on the list of priorities. The \\
\hline prioriteringar och få göra saker. Så är det barnen först & children come first, then my husband, and then maybe \\
\hline och sen kommer min man och sen, sen kanske jag kan & I can get to do something...if I can give up control and \\
\hline göra nåt... om jag kan släppa kontrollen och sen känna & feel that it's OK for me to take up some space..." \\
\hline att det är okej att jag också tar lite plats..." & \\
\hline "Jag tar ut min egentid på kvällen. När andra & "I take me-time in the evenings. When the others \\
\hline sover. Då, då tar jag min tid. Framför allt att jag & are asleep. That's when I take time to myself. I \\
\hline tittar på en film eller TV eller sitter framför datorn & mainly watch a movie, or sit in front of the \\
\hline och spelar spel eller så, är för mig själv... då & computer playing a game, spend time on my \\
\hline stänger man bort allt annat och bara koncentrerar & own... I can shut out everything else and just focus \\
\hline sig på det en stund. Och det är skönt." & on that for a while instead. That's nice" \\
\hline "Jag är aldrig avkopplad, är jag inte... tankarna går i & "I never feel relaxed, I never do... I keep thinking \\
\hline ett. Det är därför jag alltid har musik på för då hör jag & about things. That's why I always have music on, \\
\hline inte mina egna tankar, utan då koncentrerar man sig & because then I can't hear my own thoughts, and I \\
\hline på musiken istället, och då blir det väl ett slags & can focus on the music instead. I suppose that's a \\
\hline avslappnande det..." & form of relaxation..." \\
\hline
\end{tabular}




\begin{tabular}{|c|c|}
\hline "... när man är ute, man rensar tankar på ett annat & "When I'm outside I can clear my head in a different \\
\hline $\begin{array}{l}\text { sätt, och då går man och tänker på det där kanske som } \\
\text { kommer på kvällarna istället nu. Dom gångerna man } \\
\text { är ute och går känner man 'Gud vad skönt det är'. Och } \\
\text { då kan man slå bort dom där tankarna sen." }\end{array}$ & $\begin{array}{l}\text { way, and I think about the things that I would } \\
\text { perhaps think about at night otherwise. The times } \\
\text { I'm outside, I feel like 'God, this is good'. And then I } \\
\text { can fend off those thoughts later." }\end{array}$ \\
\hline $\begin{array}{l}\text { "... då kom vi iväg och det var ju, det var väldigt } \\
\text { häftigt, det var, liksom få två-tre timmar bara för oss, } \\
\text { det var coolt, det var liksom första gången verkligen, } \\
\text { så det var bra..." }\end{array}$ & $\begin{array}{l}\text { "Then we got away, and that was awesome. It was } \\
\text { like two-three hours to ourselves. That was cool, it } \\
\text { was like the first time, so that was good..." }\end{array}$ \\
\hline
\end{tabular}

